\title{
Democratic Autonomy: Public Reasoning about the Ends of Policy
}

Henry S. Richardson

Oxford University Press, Oxford \& New York, 2002, 316pp.

ISBN: 0195150910.

\section{Democracy Defended}

Gerry Mackie

Cambridge University Press, Cambridge \& New York, 2003, 483pp.

ISBN: 0521534313.

\section{Political Theory of Global Justice: A Cosmopolitan Case for the World State}

Luis Cabrera

Routledge, London \& New York, 2004, 215pp.

ISBN: 0415700221.

Contemporary Political Theory (2006) 5, 220-224. doi:10.1057/palgrave.cpt.9300224

In the latest issue of the UK-based Centre for the Study of Democracy, Keane asks 'Can an ideal backed up by little platoons of clashing metaphors and colliding justifications be anything other than essentially contested even downright incoherent?' (Keane, 2004-2005, p. 2). Democracy is a particularly ubiquitous concept at the moment and its relationship to political theory more generally is far from clear. The question of whether democracy is a desirable political ideal has tended to focus upon theorizations of what constitutes the democratic ideal, rather than how democratic ideals can be actualized in institutions. As well as this, the acceptance of democracy as a universal norm by some suggests that this is both achievable and desirable. As this review is being written, Iraqis are going to the polls for the first time in 50 years to elect a 275 -seat transitional National Assembly. As world events unfold it becomes apparent that the nexus of democratic theory, practice and experience continues to be a rich source of lived reality to complement and question ongoing theorizations of democracy and democratization processes. One of the most striking aspects of any analysis of contemporary democratic theory and practice is the sheer range of different approaches to the subject matter. This is most certainly the case in reviewing these contemporary contributions to the ongoing discussions.

Richardson's Democratic Autonomy: Public Reasoning about the Ends of Policy, part of the Oxford Political Theory Series, takes four strands of the democratic ideal - liberalism, republicanism, rationalism, and populism - to create a conception of democracy as democratic autonomy, that he distinguishes from Held (1987) in two ways (p. 255). He outlines a conception 
of democratic reasoning to highlight what is at stake when we reason democratically together, and also to address the problem of bureaucratic domination. For Richardson, bureaucracy poses a threat to democracy, however democracy is conceptualized. The policy making power that resides in administrative hands, and is counted on by modern states and provincial and transnational governments, is hard to control in practical terms and difficult to reconcile with the democratic ideal (p. 3). While acknowledging that discretionary administrative power is part of the permanent landscape of modern governments, including democratic ones, Richardson's concern is whether this discretionary power will be used arbitrarily. When this happens, administrative power creates an illegitimate type of domination that exists independently of a democratically elected legislature, yet 'this kind of nondemocratic domination plainly coexists with a democratically elected legislature' (p. 4). This is a structural issue that goes to the centre of democratic legitimacy (p. 6).

In drawing attention to the way in which administrative power can be at odds with the democratic ideal of popular sovereignty, Richardson accepts that some administrative power is inevitable and to be welcomed from a republican perspective (p. 7). It is imperative that democratic theory take seriously ways that bureaucratic domination can be avoided and whether this type of administrative discretion is actually compatible with rule by the people. The interpretation of the excesses or otherwise of administrative abuses of public power depend on political positioning. Richardson understands bureaucratic domination to be a major political problem. It also has serious implications for normative political theory, as it creates challenges to the understandings of democratic theory. Moreover, this theoretical problem is a political problem insofar as there is a lack of conceptual clarity surrounding notions of the democratic ideal and what it requires of citizens, suggesting an ill-prepared capacity to protect and preserve it (p. 8). Richardson's conceptualization of democratic reasoning contrasts with understandings of public reason and public reasoning providing a non-instrumental reasoning in which ends are newly established, revised, and specified in a flexible consideration of the obstacles that arise in settling on acceptable means for our ends' (p. 248). This conceptualization of reasoning is democratic, in that it describes how the collective reasoning actuates procedures for electing representatives, voting on legislation and implementing policy. Agency reasoning must be incorporated, both in theory and practice, as part of people's democratic reasoning to ensure that the problem of bureaucratic domination is met headon (p. 251).

Mackie's Democracy Defended is part of the Cambridge Contemporary Political Theory Series. Democratization is one of the main political trends in the world today, and yet the main intellectual view of democracy in contemporary American political science is that democracy is 'chaotic, 
arbitrary, meaningless, and impossible' (p. 2). This understanding can be traced to the influence of economist Kenneth Arrow's impossibility theorem that was applied to the study of politics by the late William Riker. In the context of earlier critiques of democracy by Mosca, Michels, and Pareto, Riker promoted a particular understanding of Arrow's theorem, forming the basis of positive political theory as a scientific understanding of political studies. Riker distinguished between a populist understanding of democracy, understood as being about the opinion and will of the people and about public policy, and a liberalist understanding of democracy based upon the view that only voting results in the placing of elected officials. Riker discounts populist democracy in favour of liberalist democracy. For Mackie, democracy is largely understood in terms of the populist version, and he argues that Riker's liberalist alternative fails both descriptively and normatively. 'I am tempted to label his doctrine antidemocratic. I believe it is antidemocratic in consequence, whether or not it is antidemocratic in spirit' (p. 3). Having come from a background with a diverse range of experience in lobbying and policymaking, Mackie was alarmed by the 'irrationalist dogma' he found in the political science literature. The 'elegant models of impossibility and disequilibrium' he learned at university sat uneasily with his own democratic experiences (p. 3).

A key aim of Mackie's work is to demonstrate that Riker's irrationalist doctrine is mistaken and to attempt to give democracy the credibility of an intellectually respectable method to come to terms with human organization. Referring to 'Commander Riker and Starship Rochester', Mackie claims that 'the Rikerian legacy is the most influential force in the discipline of political science, but its reign is controversial' (p. 23). An exhaustive overview of the literature of the particular subcultures in political science attempts to reveal that there is an irrationalist trend, as well as 'a long dark shadow' existing over democratic politics. In relation to Arrow's theorem and related social choice theory, Mackie claims 'it will take a good deal of spit to displace that ocean of theory' (p. 16). He argues that irrationalist interpretations of social choice theory are based upon erroneous assumptions, 'or illustrate logical possibilities rather than empirical probabilities, or emphasize remediable problems, or are outright mistaken' (p. 16). He insists that the irrationalist doctrines he criticises 'are not Arrow's, they are based on interpretations by others of Arrow's theorem' (p. 16). The book can be divided into three key areas. The first presents the theory of democratic irrationalism and criticizes it. Mackie distinguishes the doctrine of democratic irrationalism from rational choice theory generally, qualifying his support for rational choice theory. The second overviews the empirical examples used by the 'irrationalists' to explain and authenticate their theoretical positioning providing a critique of each example, and the third sets the centrality of positive political theory in its wider political and intellectual context. 
Cabrera's Political Theory of Global Justice: A Cosmopolitan Case for the World State forms part of the Routledge Innovations in Political Theory series. The book is about world government and the increasing economic integration impacting upon the lives of millions of people around the world. The cosmopolitan approach to distributive justice broadly advocates that moral and political boundaries are not parallel and that we are morally obligated to other human beings beyond our immediate fellow citizens within politically determined state borders. Cabrera distinguishes between moral cosmopolitans who advocate modest proposals such as aid and finance relief for poorer countries, limited institutional cosmopolitans who support partial restructuring and cosmopolitan democrats who advocate deeper near term institutional changes based upon democratic accountability in a globalized system in the context of countries continually losing ground in attempts to control their own domestic policies. He goes on to develop the approach of strong institutional cosmopolitanism claiming that seriously considering moral institutionalism commits us to strong institutional cosmopolitanism, and in particular the development of a range of strong democratic institutions beyond the nation state (p. 2). A fully integrated world government could ensure that anyone born anywhere has access to a decent life. He concedes that even if full global government was not achievable, the creation of democratically accountable supranational bodies that oversee the distribution of resources over large geographical areas would be an improvement on the current system in place at the global level.

Cabrera had previously been a staff reporter for the Associated Press who had covered the infamous 1999 WTO Ministerial Meeting in Seattle. What struck him at the time was the question of why so many of the demonstrators insisted that this round of trade talks should be called off rather than demanding that there be a place in the negotiations for civil society. Watching events unfold since then increased his conviction that economic integration at the regional and global level created significant possibilities for less affluent states. He also realized, in the context of continuing protests against international economic bodies, that the message sent by civil society about economic integration is crucial.

Another key aspect of this book is the question of what type of rights all persons have to adequate life resources and what types of institutions could bring about the actuality of these rights. Cabrera wants to shift the focus of debates away from dismantling international bodies such as the WTO and NAFTA, and towards encouraging dialogue about how more transparent and democratically accountable international governance can be achieved (p. xiv). If it is not presumed that democracy is based upon ethno-national grounds, what could constitute the grounds for a transnational democratic polity? Cabrera supports the move towards a model of popular governance and liberal 
democratic principles, institutions and political culture (p. 109). He cites Habermas, as an advocate of this type of civic nationalism or cosmopolitan patriotism, who rejects the view that democracy in Europe cannot work because there is no unified European people. Developing a trans-state public sphere, with the participating individuals affected by common public policies, could develop social solidarity not grounded on national sentiment (p. 109). The economic integration that is already underway can be made significantly more accountable through popular pressure that is exerted upon national leaders and supranational organizations.

\section{References}

Held, D. (1987) Models of Democracy, Cambridge: Polity Press.

Keane, J. (2004-2005) 'Humble democracy?' CSD Bulletin 11(2)-12(1): 1-2.

Mary Walsh

Division of Business, Law \& Information Sciences, University of Canberra, Australia.

\section{Spaces of Democracy: Geographical Perspectives on Citizenship, Participation and Representation}

Clive Barnett and Murray Low (eds.)

Sage Publications, London, Thousand Oaks \& New Delhi, 2004, 253pp. ISBN: 0761947345.

Contemporary Political Theory (2006) 5, 224-226. doi:10.1057/palgrave.cpt.9300225

In Spaces of Democracy, Barnett and Low distinguish between democracy as an ideal referring to political rule by the people and democracy as a set of processes and procedures. While there has been a seemingly universal acceptance of democracy as an ideal in the last two decades, there is dispute about procedures and processes for making the ideal into practices of institutionalized democracy. Their key starting point is not the question What is democracy? but rather Where is democracy? They are struck by the realization that processes of democratization, or democracy in a more general sense, have had limited influence on the research agenda of human geography. Their general aim is to rectify this situation by encouraging critical engagement with issues of normative political theory. Barnett and Low refer to the 'ghostly presence of democracy in geography' (p. 1) claiming that critical analysis of democratic procedures of participation and representation remains largely marginalized, constrained at a more fundamental level by understandings of 